\title{
A Justification, after the Postmodern Turn, of Universal Ethical Principles and Educational Ideals. ${ }^{1}$
}

\author{
MARK MASON \\ Faculty of Education, The University of Hong Kong
}

\begin{abstract}
The implementation of education programmes in different cultures begs the question whether we are justified in doing so in cultures that may reject the programmes' underlying principles. Are there indeed ethical principles and educational ideals that can be justified as applicable to all cultures? After a consideration of Zygmunt Bauman's postmodern rejection of the possibility of universal ethics, I cite and extend Harvey Siegel's defence of multiculturalism as a transcultural ethical ideal. I conclude the paper with a justification of the transcultural normative reach of moral principles that I have elsewhere defended as the ethics of integrity. The paper's significance lies in its justification of educational interventions founded in these principles across different cultures.
\end{abstract}

\section{Introduction}

"Skander allowed his wife to attend literacy classes on two conditions: that she be accompanied by his mother and that the textbook used in class not be brought home. This is not yet another account of a far-flung Third World community. This happens in Europe - in post-war Kosovo, where the patriarchal, traditional culture continues to isolate Kosovo Albanian women to the extent that large numbers of them are illiterate.” (Education Today, the newsletter of UNESCO’s education sector, 2002.)

The implementation of education programmes in different cultures across the world raises difficult ethical problems. Programmes, such as that cited here, might be motivated by a belief in the right of all to literacy. But such values might challenge the traditions and beliefs 
of members of different cultures, might indeed challenge the very fabric of their worldview and sources of existential meaning. A question associated with these problems is whether we are justified in implementing programmes founded in principles of equal respect and dignity in cultures that reject the ways in which we give expression to these principles. Some cultures may not share our notions of equal respect and dignity when it comes to women, members of other ethnic groups and of lower castes, the poor, children. The question, in other words, is whether there are ethical principles and educational ideals that can be justified as applicable to all cultures, whether or not those cultures reject such principles and ideals. And if there are, how might we defend them?

My thesis in this paper is that there are principles and ideals that are transcultural, that are universal. My aim here is to justify them. Following the postmodern turn and the concomitant denial of the possibility of universal ethics, strong multiculturalist positions hold that imposing our principles, which are in their view culturally specific, on other cultures that reject those principles, is morally illegitimate. Against these claims, I show in this paper why some universal ethical principles are indeed applicable to all cultures.

I draw on the literature of postmodern ethics - in particular, on the work of Zygmunt Bauman - to show its relevance for understanding the nature of moral comportment in contemporary society. At the end of the paper I aim both to challenge some aspects of the postmodern moral perspective and to build on the intuitionist ethics underlying it. I argue against strong postmodernism's unqualified celebration of difference, given its association with moral relativism. I conclude the paper with a justification of moral principles, which I have elsewhere defended as the ethics of integrity (Mason, 2001), that might underpin universally the adjudication of acceptable educational and other practices from the unacceptable.

Prior to those conclusions I engage with the principles and issues associated with multiculturalism, drawing on the arguments of Harvey Siegel to conclude that contained within the principle of multiculturalism itself is the obligation to respect the dignity of each other, and especially of those who are different, as persons. Such a principle is, as Siegel shows, universally applicable to all cultures. What this means is that cultural practices that are disrespectful of the rights of, for example, women, other ethnic groups, lower castes, the 
poor, or children, may justifiably be understood as morally illegitimate. What this also means is that policies and programmes that challenge such practices are morally justifiable.

The outcome of this paper is thus a description and defence of some ethical principles and educational ideals that are universal and applicable transculturally. The significance of this position is that it offers a justification for educational interventions founded in these principles and ideals across different cultures, even and especially those cultures that might reject these principles and ideals. At a time when diversity is celebrated, when we know the importance of treading sensitively where the traditions and beliefs of others who are different are concerned, my arguments and conclusions may appear rather controversial. And a careless interpretation of this position might well have consequences that are oppressive of those who are different. But I hope I will have shown in this paper that embracing its conclusions of ethical universality is all the more morally responsible.

\section{Ethics in an increasingly globalized and multicultural world ${ }^{2}$}

I turn first to Bauman for an understanding of the nature of ethics and morality in our increasingly globalized and multicultural world; for an understanding of why it has been described as postmodern, and what the postmodern perspective on contemporary ethics entails. My aim here is to understand why we have so much less faith today in what we used to be certain was right, good and true; to understand why phrases such as 'the celebration of diversity' and 'respect for difference' are so popular today; and why the problems associated with moral relativism loom large. ${ }^{3}$

Giddens maintains that "globalization ... is not the same as internationalization. It is not just about closer ties between nations, but concerns processes, such as the emergence of global civil society, that cut across the borders of nations” (1998, p. 137). Waters (1995, p. 3) offers an excellent definition of globalization: “A social process in which the constraints of geography on social and cultural arrangements recede and in which people become increasingly aware that they are receding”. It is about, in Delanty’s version, the diminishing importance of geographical constraints in defining the nature of economic, political, social and cultural interactions; in other words, about the transformation of space or, more specifically, the “deterritorialization of space” (2000, p. 81). Cultures and civilizations are 
thus more exposed to each other, more likely to clash, or to merge, or to develop new hybrids or a universal culture, with as much impact on the local and specific as on the global and universal, as a consequence of the diminishing limits of geography. It should be stressed, however, that globalization by no means leads necessarily to a global society, and not even to a global culture (other than perhaps the rule of the market and its orientation towards global elites as a consequence of the transnationalization of capitalism). Most of the literature points as much to increasing diversity and fragmentation as it does to increasing homogeneity. It is in the moral questions raised by this diversity and fragmentation that I am interested in this paper.

In his seminal work, Postmodern Ethics, Bauman (1993, pp. 17-20) outlines four moral characteristics of late modernity, which, I should point out, are not necessarily unique to late modern societies, but are certainly more prevalent, with greater compounding effects, in late modernity.

ـ First, given the diversity, complexity and increasingly globalized nature of a world constituted by infinitely many social interactions, our actions have consequences far beyond what we could ever imagine - and we just do not have the ethical rules to guide actions whose consequences cannot be foreseen. One man from south China, suffering from fever and flu-like symptoms when he travelled to Hong Kong in early 2003 for a wedding, could not have known that his decision would help to spread the pneumonia-like illness SARS from Guangdong province around the world via Hong Kong's globally connected airline hub.

a Second, the division of labour that characterizes the work we do means that we are just 'bit players' in the production of a final outcome. Without being able to claim sole authorship for outcomes, we do not easily accept responsibility for their consequences. Who is to blame for the deaths of the civilian families wiped out in the invasion of Iraq when a US aircraft bombed houses in Basra in an attempt to kill the man known as “Chemical Ali”? The special operations commander who called in the attack? The pilot? The military field commander? The US Secretary for Defence? The US President? 
a Third, our existence is fragmented into the temporary occupation of many different roles, none of which might be sufficiently important to define our identity. We therefore do not readily take responsibility for the consequences of the roles we temporarily occupy, since our occupation of the role is so fleeting as not to make it meaningfully constitutive of our identity. Hence there is no necessary consistency or moral responsibility that flows evenly through all of our actions. If I am for the most part of the week a working man and a family man, and for only part of the weekend a football hooligan, this lesser part of my identity helps me to feel little responsibility for the victims of my thuggery.

a Fourth, the moral discomfort of the consequences of our actions of course sometimes sticks, and we then seek the authority of rules to which we can turn for guidance. But modernity has lessened our faith in our traditional sources of religious authority, and we are unsure of which ethical code to follow. Obedience to one authority implies disobedience to another. In our multicultural world, we are well aware that others follow different gods to the ones we might worship. Hence the moral ambiguity of our times. What has been described as the 'postmodern moral crisis' lies in the realization that sources of moral authority to which we might have traditionally turned are contested, and there is consequently no given source of right action.

Bauman conceptualizes the postmodern perspective as concerned with the unmasking of the "illusions" of modernity, arguing that the essence of the postmodern approach to ethics lies in "the rejection of ... the philosophical search for absolutes, universals and foundations in theory” (ibid., p. 4). Our search for these absolutes, universals and foundations has probably been tempered by our realization, as a consequence of the multicultural spaces we now inhabit in an increasingly globalized world, that ours is a plural world, with a diversity of perspectives and claims to truth, beauty, and goodness. And our "coercive normative” (ibid.) and regulatory response to moral challenges in political practice has probably been tempered by our horror at the cruelty and suffering we have witnessed at the height of modernity in the twentieth century. The Soviet state's attempts at rational planning and management of virtually every aspect of its citizens' lives resulted in the death of millions under Stalin's rule on a scale the likes of which had never been seen, even under the Tsars. The Nazis' systematic attempts to exterminate the entire Jewish population of Europe resulted in a holocaust of six million dead in the likes of Auschwitz and Birkenau. The South African 
apartheid state's attempts to re-design and engineer an entire society along racial lines through legislated ethnicity resulted in untold misery for millions at the hands of a relatively small militarized bureaucracy. This human cruelty and suffering is not unique to the high modern era: terror in all its forms has been a fact of history. What is awful about this terror is its scale, made possible by the technology and bureaucracy of modernity, which allowed systematically and rationally planned large-scale execution, in an era when we had available to us the constitutional arrangements of liberalism and democracy. Our scepticism towards the "search for absolutes" and "coercive normative regulation" is because of what we have been witness to this past century. Hence the celebration of diversity and plurality in the postmodern perspective. Hence the abandonment of coercive and regulatory ethical codes.

Postmodern ethics is thus, to use Bauman’s (ibid., p. 31) aphorism, “morality without ethical code". While the moral thought and practice of modernity may have been "animated by the belief in the possibility of a non-ambivalent, non-aporetic ethical code”, what is postmodern is the "disbelief in such a possibility" (ibid., pp. 9, 10): post not in the chronological sense, but in the sense of offering a critique of modernity. The postmodern insight into morality is that in an era when the range of our moral choices and the consequences of our actions are more far-reaching than ever before, we are unable to rely on a universal ethical code that would yield unambiguously good solutions:

Human reality is messy and ambiguous - and so moral decisions, unlike abstract ethical principles, are ambivalent. It is in this sort of world that we must live .... Knowing that to be the truth ... is to be postmodern. Postmodernity, one may say, is modernity without illusions .... The illusions in question boil down to the belief that the 'messiness' of the human world is but a temporary and repairable state, sooner or later to be replaced by the orderly and systematic rule of reason. The truth in question is that the 'messiness' will stay whatever we do or know, that the little orders and 'systems' we carve out in the world are ... as arbitrary and in the end contingent as their alternatives (ibid., pp. 32-33).

This last assertion of Bauman's, that any ethics is as "arbitrary” and "contingent” as any other, is not necessarily consequent on his characterization of "human reality" as "messy and ambiguous”. I have shown elsewhere (Mason, 2001) that an ethics that is not arbitrary and 
contingent can be derived from his characterization of postmodern morality, and I will return to this question in the latter part of the paper.

Bauman outlines seven or eight characteristics of the moral condition from a postmodern perspective, some of which are relevant for our purposes here:

ـ First, humans are morally ambivalent: they are neither essentially good nor essentially bad. Postmodern ethics holds that it is therefore impossible to design a coherent ethical code to accommodate our ultimately ambivalent moral condition.

a Second, moral phenomena have nothing to do with the rational "consideration of purpose [or] the calculation of gains and losses” (1993, p. 11). What Bauman means when he describes moral phenomena as inherently non-rational may be difficult to understand in an age of reason where we take the possibility of moral reflection and reason almost for granted. Perhaps the best way to understand his position is by analogy with the nature of love. Love, we accept, is not a product of reason or reflection; it is not a conclusion we can reach rationally. A demonstrative gesture is, after all, only truly affectionate if it is spontaneous. A calculated demonstration of affection would hardly count as such, and would probably be better interpreted in terms of its instrumental purposes. Bauman understands morality in similar vein. For him, moral action ceases to be moral if it is the result of a rational decision. Its rational calculation makes it susceptible to instrumental interpretation. It would smack of an ulterior motive, of heteronomous obeisance to the authority of an external code, or simply of duty in the Kantian sense. Bauman's moral universe is infinitely larger than what he perceives as the shrunken universe of Kant's duty-bound morality. The spontaneity of moral action, and this is its essence, lies in our infinite responsibility to the Other (for whom we are unboundedly responsible in our face-toface relationship with him or her), and in our conscience, unmediated by reason.

a The third characteristic of the moral condition from a postmodern perspective is that morality is always fraught with irreconcilable contradictions, since few choices (other than the relatively trivial and the existentially uninteresting) produce unambiguously good consequences. Modernity's quest for ethical certainty is therefore impossible. 
口 Fourth, morality cannot be universalized: attempts to universalize morality merely substitute "heteronomous ... ethical rules for the autonomous responsibility of the moral self” (ibid., p. 12).

- Fifth, Bauman claims that the postmodern perspective on moral phenomena does not lead to moral relativism: his negation of the universalizability of morality is not an endorsement of moral relativism. He agrees that moral relativism has nihilistic implications, placing his faith instead in our essentially human moral capacity. It is rather the existence of competing ethical codes that gives rise to relativism.

\ Although Bauman doesn't specifically delineate the following characteristic of the moral condition in a postmodern perspective, what is evident in his and other postmodern writing is that postmodern morality is non-foundational: there exist no $a$ priori foundations of morality on which universal ethical codes can be built. He cautions instead that postmodern ethics will yield no ethical code, not even a local one.

These elucidations of the postmodern perspective on ethics in our contemporary world should make it clear why we have so little faith in what we used to be certain was right, good and true. And if we now have so little faith in what we used to know to be the right thing to do, how much less faith do we have in the applicability of our (now more tenuously held) beliefs and practices in other cultures? In a globalized world we are more aware of the cultural beliefs and practices of others, and in our humility that followed our own collapse of faith, we have learned to become more sensitive to different ways of doing things. In such a world, is it possible that we might still be able to defend principles that have normative reach across cultures? Is it possible, for example, to defend universal notions of human rights? I return to the problem and question I posed in an introductory paragraph to this paper: are there ethical principles and educational ideals that can be justified as applicable to all cultures, whether or not those cultures reject such principles and ideals? And if there are, how might we defend them?

To answer this question, I turn now to Siegel's position, before turning to my own work to complete all the steps of the argument. 


\section{Multiculturalism and the possibility of transcultural educational ideals}

In his paper, Multiculturalism and the possibility of transcultural educational and philosophical ideals, Siegel (2002) turns his attention to this very question. He starts by defining multiculturalism (ibid., p. 26) as

That movement in contemporary social/political/educational thought - and the claims, theses and values which characterize it - which celebrates cultural differences; insists upon the just, respectful treatment of members of all cultures, especially those which have historically been the victims of domination and oppression; and emphasizes the integrity of historically marginalized cultures.

To set his argument in the context of our discussion thus far, it is worth sketching a rudimentary and rather over-simplified dichotomy, with the multiculturalists at one pole, and the universalists at the other. With the multiculturalist position are generally associated the notions of a celebration of diversity and difference; a belief in cultural and moral, even epistemological, relativism; the consequent denial of the possibility of any universal notions of truth, right, goodness or beauty; and the view that any attempt to define any such universal notion is misguided, colonialist, and oppressive in its denial and silencing of the voice of other, marginalized, cultures. With the universalist position, on the other hand, is generally associated the view that it is possible to defend a universal notion of truth and universal notions of what is right and good. The universalist may accept the fact of cultural relativism, but not the truth of epistemological or moral relativism.

Siegel attempts, and I think succeeds in, a defence of the possibility of transcultural educational and philosophical ideals. He does this by setting out what a commitment to multiculturalism entails, and finds in this a commitment to at least one transcultural moral principle: respect for the rights of others. In fact, as we shall see, he is able to defend a few transcultural moral and epistemological principles.

Siegel (ibid., p. 29) sets out the justification of the multiculturalist position thus: 
1. Educational/philosophical ideals are meaningful, applicable, or relevant only within the particular cultures which acknowledge and embrace them.

2. Therefore, there can be no absolute, universal, or transcultural ideals.

3. There can be no culture-neutral standpoint - none is 'philosophically available' - from which fairly and impartially to evaluate alternative, culturally-relative ideals.

4. Therefore, the imposition or hegemony of culturally specific ideals upon other cultures which do not recognize the legitimacy of those ideals cannot be morally justified.

5. Reason therefore requires that cultures tolerate, and recognize the culturespecific legitimacy of, the ideals of other cultures. This commitment to multiculturalism demands that all cultures accept the legitimacy of all other cultures living in accordance with their own, culturally-specific ideals.

Siegel then points out that the conclusion equivocates on two senses of "legitimacy". It is, he reminds us, one thing to say that "educational and philosophical ideals are necessarily culture-specific - legitimate only intra-culturally - in that the legitimacy or force of such ideals does not extend beyond the bounds of the cultures which embrace them” (ibid.) (a culture-specific sense of legitimacy). But is quite another to say that "all cultures must accept the legitimacy of all other cultures living in accordance with their own, culturally-specific ideals” (ibid., p. 30) (a transcultural or universal sense of legitimacy). The first, he points out, "denies the possibility of transcultural legitimacy", while the second "propounds the transcultural duty to accept every culture's right to live in accordance with its own ideals” (ibid.).

Despite this equivocation, the multiculturalist would obviously be keen to hold to both senses of legitimacy. Her argument would commit her to the first sense that educational and philosophical ideals are legitimate only within the bounds of a particular culture because she would reject any culture’s attempts to establish hegemony over another by “unjustifiably dictating the terms of cultural adequacy to other cultures" (ibid.). Think of the educational injustices in presenting only the values and history of the dominant culture as legitimate in curricula and textbooks meant also for children from minority cultures. She would want those values presented as specific to and legitimate only within that particular culture. But 
her argument would also commit her to the second, transcultural sense of legitimacy, that we all have a duty to respect the right of every culture to live according to its own ideals and values. Continuing our example, she would want the dominant culture to respect the values and history of minority cultures by presenting them as legitimate in the curricula and textbooks as well.

She obviously cannot embrace both a culture-specific and a transcultural sense of the term. And giving up both would mean giving up her commitment to multiculturalism. So she's got to give up one, but it cannot be the second, transcultural sense, that she foregoes, for if she does, then "there is nothing to underwrite the multiculturalist's sense of moral outrage over what she perceives to be the patent injustices perpetrated by an indefensible cultural hegemony" (ibid., p. 31).

Here then is an argument based on the principle of rational consistency that, if we accept the principle of multiculturalism, we must accept this principle transculturally or universally: that is, that we all have a duty to respect the right of every culture to live according to its own ideals and values.

But what of those who reject the principle of rational consistency? It should be clear that the rational advocacy of multiculturalism presupposes "the transcultural character of the normative force of arguments as such” (ibid., p. 36). In other words, if one is committed to multiculturalism, one is also committed to rationality, to accepting that which is justified by reasons, as a transcultural ideal. How else would one convince a culture other than one's own to respect the rights of other cultures? To those who would critique the transcultural normative force of rationality, who would question our being bound to accept that which is justified by reasons, I would ask, “Critique in the name of what?”. Even to ask for a justification of rationality is to ask for a rational justification of it, a point made by Siegel in Rationality Redeemed? (1997), and by Nicholas Rescher in his seminal work on rationality (1988).

There is, Siegel points out, a deeper reason why the multiculturalist needs to give up her culture-specific sense of legitimacy. This reason lies in the moral domain. It follows from the multiculturalist's assertion that "all persons and cultures are morally obliged to treat cultures other than their own, and the members of those cultures, justly, with respect, in ways 
which do not silence, marginalize, or oppress” (2002, p. 31). Significantly, multiculturalists do not limit this moral obligation to those cultures that recognize it; it applies, they assert, to cultures that do not even acknowledge that it does. The justification for this assertion lies in the position that it is simply morally wrong to treat other cultures and the members of those cultures unjustly, without respect and in ways that oppress them. "As educators”, claims Siegel, "we are obliged to embrace multiculturalism - irrespective of the cultural context in which we find ourselves - simply because we are morally obliged to treat cultures other than our own, and the members of those cultures, justly and with respect” (ibid.). Other writers have also asserted that multiculturalism and multicultural education rest on commitments to transcultural values such as "the fostering of critical judgement and of equality, justice, and human dignity” (Robert Fullinwider, 1996, pp. 9, 13-16); “universalist values such as equal liberty, opportunity, and mutual respect among citizens” (Amy Gutmann, 1996, p. 162); and the "universalist basis" of "the politics of difference" (Charles Taylor, 1992, p. 38).

Siegel (2002, p. 31) reminds us how this obligation to treat other cultures justly and with respect cannot simply be a culturally-relative truth, one that is true only from the perspective of a particular culture. If it were regarded thus, the monoculturalist would simply claim that while you may hold this principle, it's not true from his cultural perspective. The multiculturalist has no response to this unless she sees the principle of multiculturalism, with its attendant moral principles of justice and respect, as universal moral truths, applicable to all cultures, including those that do not recognize them as moral truths.

Here then is an argument based on the moral principle of respect for others that, if we accept the principle of multiculturalism, we must accept this principle transculturally or universally: that is, that we all have a duty to respect the right of every culture to live according to its own ideals and values.

To return to the justification of the multiculturalist position and, in particular, the equivocation on "legitimacy" in Point 5, its last sentence needs to be modified thus:

"all cultures must accept the legitimacy of all other cultures living in accordance with their own, culturally-specific ideals, in so far as those culturally-specific ideals and attendant practices are consistent with the moral imperatives of multiculturalism itself' (ibid., p. 32). 
In other words, the advocate of multiculturalism need not and in fact should not "regard as legitimate all culturally-specific ideals and practices, but only those which do not violate the multiculturalist ideal itself” (ibid.), and which do not violate the principles of justice and respect that are contained within this ideal. The multiculturalist must, in other words, "reject the idea that cultural values and ideals have legitimacy only within cultures” (ibid.). Here are grounds then to reject, even to condemn, practices in our own and in other cultures that violate the principle of multiculturalism and its associated principles, respect for others and justice as fairness. As Siegel concludes,

Taking the moral/political directives of multiculturalism seriously ... requires that it be understood transculturally, with teeth enough to criticize effectively objectionable cultural hegemony and to justify advocating and working towards the establishment of institutions which respect the integrity of all cultures (in so far as their ideals and practices are consistent with the multicultural ideal itself). (ibid., p. 34)

What have we established so far? That "multiculturalism is itself a culturally transcendent or universal moral, educational and social ideal in the sense that it is applicable to all cultures, even those which do not recognize or embrace it” (ibid., p. 33). And that within this are contained further universal, “equally transcendent, moral imperatives and values” (ibid.): those that we have identified such as the obligation "to treat cultures other than [one's] own, and the members of those cultures, justly, with respect, in ways which do not silence, marginalize, or oppress” (ibid., p. 31). We have also identified, in the epistemological domain, "the transcultural character of the normative force of arguments as such" (ibid., p. 36): rationality is thus a further transcultural educational and philosophical ideal.

We have considered potential objections to the principle of rational consistency. But we have still to consider potential objections to the moral principles associated with multiculturalism. What are the grounds for honouring the principles associated with multiculturalism identified by Siegel, Fullinwider, Gutmann, and Taylor? These principles include the equality of all persons as persons, equal liberty, justice, human dignity, and respect. And what of those who reject the moral principle of respect for others? Are there ways in which we can justify these as transcultural moral principles? I have elsewhere defended the injunction to respect the 
dignity of our and each other's being as one of two principles that constitute the ethics of integrity, which, I have argued, can be defended as universally applicable (Mason, 2001). I shall turn to my own arguments in defence of the ethics of integrity in the following section.

Those who reject the principles of the equality of all persons as persons, equal liberty, justice, human dignity, and respect could only go so far as to claim that such principles are local, specific to a particular culture, and therefore have no transcultural normative reach; that is, that they cannot be universal. But this dichotomy of local versus universal is a false one. As Siegel makes clear:

\begin{abstract}
All principles, values and ideals - indeed, all beliefs, theories and judgements more generally - are conceived and embraced (if at all) only in particular locales; whether or not any of them enjoy legitimacy beyond the bounds of those locales is an independent matter. When such legitimacy extends across all local boundaries, they are both local and universal. This dichotomy is a false one - and so, one cannot reject universality on the grounds that all ideals are local, either in origin or in current acknowledgement and acceptance.
\end{abstract} (2002, p. 37)

Another way in which the possibility of universal principles, values or ideals is rejected is by means of the claim that there is no 'God's eye view' or transhistorical, context-free position from which to derive them, a claim most commonly associated with Richard Rorty. Rorty rejects the search for “an Archimedean point from which to survey culture” (1982, p. 150). In his well-known paper, Solidarity or Objectivity, Rorty (1985) argues that there is no noncircular way to justify our own ideals to those who reject them in favour of their own equally ethnocentric alternatives. David Theo Goldberg, in summarizing Rorty’s position, puts it thus:

As Rorty insists, there is no transhistorical or supersocial Godly view on which such universal (moral) principles can be grounded or from which they can be derived. Axiological concepts and values are necessarily those of some historically specific community. (1994, pp. 17-18) 
Now it may well be that there is no perspective outside history, but, as Siegel makes clear, such a perspective is not a necessary foundation for a transcultural ideal. Transcultural ideals are simply those that have been born in a particular culture (and we can accept that they are contingent as well), but have transcultural normative reach as well. They do not depend on a 'view from nowhere' for their existence.

Further, it is worth noting that those who deny the possibility of transcultural normative reach are themselves assuming this principle applied to rationality in their arguments above. They appeal to rational consistency in (ultimately futilely) attempting to deny the possibility of an ideal holding locally and universally. And they employ the familiarly rational method of drawing conclusions from premises (one of which [the premise that universal ideals depend on a view from nowhere] was false) in attempting to deny the possibility of transcultural ideals because there exists no perspective outside history. In other words, they assume their conclusions have force independently of the cultural perspective of those who disagree with them: they are indeed assuming the transcultural normative reach of the force of reasons.

But there is a further important question here: what of those who reject the principle of multiculturalism in the first place? Siegel's arguments have assumed that one is committed to multiculturalism, and he has thence justified transcultural educational and philosophical ideals by arguing that they are contained within the ideal of multiculturalism itself. At its core, his argument is based on the inescapable (but not always recognized) conclusion that if we are committed to multiculturalism, we are committed to the universality of the principle of respect for the rights of others. From this we know that no culture has the right to oppress any other culture. But if, for example, a religiously fundamentalist culture rejects multiculturalism and does not accord its women the same respect accorded to men, does it mean that we should, in terms of Siegel's argument, regard such practices as illegitimate and hence condemn them? His argument, after all, assumes the premise that one is committed to multiculturalism, and this culture rejects it. Bear in mind that the committed multiculturalist (who mistakenly doesn't recognize its universal features) would regard such judgement of the practices of another culture as akin to colonialist oppression. Nevertheless, it would appear that we should, because if we are committed to multiculturalism, we are committed to the universality of the principle of respect for the rights of others, and we are thus committed to regarding as illegitimate any practices that violate this principle. While the oppression of 
women within one culture may not be a case of intercultural oppression, the generalized principle of respect must, in the view of anyone committed to multiculturalism, apply to all.

In brief summary, here are the key steps of the argument so far:

1. We are morally obliged to treat others with respect, to acknowledge the equality of all persons as persons, to respect the human dignity of all, to accord equal liberty to all, and to honour the principle of justice as fairness. These principles apply also to the treatment of one culture by another.

2. We are bound to accept the force of that which has been justified in reason, for to question that which has been justified in reason is itself to acknowledge the probative force of reasons.

3. These moral and epistemological premises commit us to the principle of multiculturalism, which requires that all cultures accept "the legitimacy of all other cultures living in accordance with their own, culturally-specific ideals, in so far as those culturally-specific ideals and attendant practices are consistent with the moral imperatives of multiculturalism itself” (Siegel 2002, p. 32), primary among which is the principle of respect for the rights of others.

What we have here are principles identified in our first and second premises that lead us to a commitment to multiculturalism, to an acceptance of its universal features, and to an acknowledgement of its transcultural normative reach and thus of the purchase of its associated principles in other cultures. We may readily acknowledge that the moral principles in the first and second premises are contingent on the worldview associated with the principles of liberalism and of the Enlightenment respectively that originated in Western philosophical thought (and indeed further back in classical Greek philosophy), for we do not need them to originate in a 'view from nowhere': we have, after all, seen how principles may originate locally and be held both locally and universally. Acceptance of these moral principles from the first premise and of the probative force of reasons from the second premise commits us to the principle of multiculturalism in the transcultural or universalist, rather than the culture-specific, sense of respecting the rights of other cultures, which in turn extends the normative reach of the principles associated with multiculturalism to other cultures. So, a commitment to multiculturalism (from which we cannot escape if we accept the above premises) commits us to the universal applicability of its associated principles, 
which commits all to the transcultural normative reach of its principles. This is precisely because if we are committed to multiculturalism, we are committed to the universality of the principle of respect for the rights of others, and we are thus committed to regarding as illegitimate any practices that violate this principle. From moral and epistemological principles that originated locally we are led inexorably to their normative reach across all cultures. It means, to answer our main question, that the implementation of education programmes in different cultures across the world, motivated, to use the example with which I introduced this paper, by a belief in the right of all to literacy, is morally justified, even if such programmes challenge the beliefs and practices of other cultures. This is a very significant conclusion, and I will say more about it in the conclusion of the paper.

To argue that certain principles that originated locally have transcultural normative reach and are binding on all is a very strong claim to make indeed. A conclusion as powerful as this may seem both frightful and frightening to some, who may accuse us of coming full circle and returning to something akin to colonialism in claiming that one culture's view of what is true, right and good is binding on other cultures. They may grant that the obligation to respect other human beings is certainly not a moral concept that emerged only in the West (and is probably honoured universally, if in different interpretations); and they may grant that the associated principles of this argument, such as the obligation to accept the probative force of reasons and to respect other cultural practices in the spirit of multiculturalism (but of course only insofar as such practices do not violate multiculturalism's associated principles), are principles worthy of claiming transcultural normative reach. But their fear may be that if we have demonstrated how some (originally) local principles have transcultural normative reach, can we not use similar arguments to claim universal applicability for other principles that could be quite objectionable? Could somebody not make parallel moves to defend as universally true and good the view that men deserve more life chances than women?

I think not. The arguments presented here are based ultimately on three concepts that are both essential to the justification of the conclusion and uniquely able to justify that conclusion. It is not, in other words, just a case of "if we accept the moral principle of respect, and if we accept the probative force of reasons, then we are committed to the principle of multiculturalism, which requires that all are committed to respecting only those practices that are consistent with multiculturalism". It is a case of "if, and only if, we accept the moral principle of respect, and if, and only if, we accept the probative force of reasons, 
then we are committed to the principle of multiculturalism, which requires that all are committed to respecting only those practices that are consistent with multiculturalism”. The premises may be accepted as sufficient, but are they indeed necessary as I have claimed? Testing the truth of the contrapositive shows that at least the first is. To show the necessity of the premise, we need to show that a commitment to multiculturalism implies a commitment to respect for others. The contrapositive is indeed true: having no respect for others certainly implies having no respect for others with different cultural practices.

But it's more than just that the moral principle of respect and the probative force of reasons are necessary and sufficient conditions for a commitment to multiculturalism. It's also that multiculturalism is a particular moral position that is uniquely able to provide the bridge in this argument from local to transcultural normative reach. It is both the principle that enjoys transcultural normative reach, and itself the bridge that enables the transcultural move. It's not just any moral principle, but the fulcrum about which such arguments turn. For the person who believes that men deserve more life chances than women to make parallel moves to defend his views as universally true and good, he would have to identify a moral principle able to do just that. So the conclusion we have reached is not as frightening or as frightful as might have been thought. It is, with its justification, the only way, as far as I can see, of reaching a conclusion with such powerful consequences of transcultural normative reach.

To return to the conclusion, there remain, however, further questions about the warrant of the premises. The second is justified, even to those who question the probative force of reasons, because, as I have indicated in the statement of the premise, even to question it is to acknowledge the probative force of reasons. But what, you may ask, of those who reject the probative force of reasons outright in favour of, say, truth as revealed by their god? What of the white supremacist who justifies apartheid by revelation from his reading of his scriptures and rejects dialogue with you? What of the religious fundamentalist who justifies his hatred and oppression of other religious groups by revelation from his scriptures? What of the cultural fundamentalist who justifies his treatment of women by revelation from his scriptures? If it's an outright rejection of dialogue, a refusal even to ask a question or to request justification, then I have to admit that I have no response. If he requests or permits none, there is nothing I can say further. I can only act in ways that prevent his harming of others in his rejection of these principles. And in a sense, his rejection of dialogue thus forces us into action guided by these principles. Our commitment to the transcultural normative reach of 
these principles is not lessened; indeed, our commitment to action in terms of these principles is strengthened.

What of the moral principles in the first premise? We may acknowledge that they are contingent on the worldview associated with the principles of liberalism that originated in Western philosophical thought (although we can be sure that the obligation to treat one's fellow humans with respect did not originate solely in the West), but why should they even be recognized and honoured in the West in the first place? Perhaps what I have defended elsewhere as the ethics of integrity, grounded in the injunction to trust your conscience, can provide a justification for the principles enunciated in the first premise. A possible counterargument may suggest not, since members of another culture may reject the injunction to trust one's conscience in favour of an injunction to abide by their scriptures and their culture's traditions and institutions. But this counter-argument fails, since we don't have to worry at this stage of justifying the premises applicable to a particular culture whether another culture rejects this injunction. If we can have the injunction accepted locally in one culture (in this case the West), we can generalize to multiculturalism in the universalist sense and thence to the transcultural normative reach of the principle of respect.

\section{The ethics of integrity ${ }^{4}$}

Many advocates of multiculturalism claim that it is "morally required that we treat students with justice and respect, in ways which do not demean, marginalize, or silence them” (ibid., p. 27). Siegel finds this assertion of this moral requirement in the likes of Charles Taylor, Henry Giroux and Peter McLaren. These are the claims of the first premise. I turn now to an attempt to justify them.

I remarked earlier that Bauman's assertion that any ethics is as "arbitrary" and "contingent" as any other is not necessarily consequent on his characterization of "human reality" as “messy and ambiguous”. I want to show very briefly here that an ethics that is not arbitrary or contingent can be derived from his characterization of postmodern morality. I will show how, by reference to Bauman's postmodern ethics, we are left with nothing but recourse to our conscience, as he admits, which commits us to a respect for ourselves and others, thence to responsibility for the consequences of our decisions, and thence to the other principles 
enunciated in the first premise. As such, I will try to move the argument beyond postmodern ethics, with which I started the paper.

Bauman's response to the ambiguity of human reality is based in his position that it is our moral capacity that essentially defines us as human beings. In a close reading of Bauman it becomes clear that he is a moral intuitionist, forsaking the "comprehensive ethical code” in favour of "human moral intuition and ability to negotiate the art and usages of living together”. Out of such a position comes the possibility of "facing human moral capacity point-blank”, of "re-personaliz[ing]" it, without a surrender to the constraints (and consequent moral absolution) of “artificially constructed ethical codes”. Significantly, this quintessential statement of postmodern morality returns to Kant's “mystery of morality inside me” (1949, p. 258) in claiming that it is the "primary 'brute fact' of moral impulse, moral responsibility, moral intimacy that supplies the stuff from which the morality of human cohabitation is made” (Bauman 1993, pp. 33, 34, 35).

Bauman seeks to avoid the universalism inherent in Kant’s (1990, p. 38) categorical imperative to "act only according to that maxim by which you can at the same time will that it should become a universal law”. But his assertion, seeking also to avoid foundations, that “if in doubt - consult your conscience” (1993, p. 250) is surprisingly close to deontological ethics. Postmodern ethics could almost be characterized - and I will show how, by reference to the moral intuitionist, W. D. Ross - in terms of an intuitionist deontology: not of course quite as deontological as Kant’s classical statement, since Bauman’s conscience-guided morality would be more sensitive to the contextual specifics of a particular dilemma than would Kant's transcendental position. We have seen that Bauman argues for the natural predispositions in conscience to act morally, quite the opposite of an ethics constituted by “artificially designed rules”. Bauman’s non-foundational “morality without ethical code” (ibid., p. 31) leaves us with little more than a claim of unbridled responsibility for the Other. For the source of this claim, Bauman turns to Levinas, who posits an inextricable link between identity and moral responsibility: "I am I," he says, “in the sole measure that I am responsible” (1985, p. 101).

It is with reference to W. D. Ross, who is generally understood as a moral intuitionist, that I characterize Bauman's argument as intuitionist. Ross argues that we have "certain basic convictions, or intuitions of conscience, about how we ought to [act]”, and that many such 
moral convictions of ordinary people are correct. "I am assuming," he says, "the correctness of some of our main convictions as to prima facie duties, or, more strictly, am claiming that we know them to be true” (emphasis original) (cited by Cottingham, 1996, p. 408). While Ross may thus appear deontological in his moral orientation, he rejects Kant's concept of categorical duties that do not countenance any exceptions. Hence his stress on the prima facie nature of duty, by which he intends that the degree of obligatoriness attaching to a particular duty depends on the circumstances, and that the duty may thus be outweighed by other duties that prevail simultaneously. It is by recourse to our basic convictions, to our intuitions of conscience, that we know which duty to honour first. Hence my characterization of Ross's ethics as intuitionist deontology. It is in this sense, and with reference to his return to Kant's “mystery of morality within me” that I mentioned earlier, that I understand Bauman's argument ultimately to be intuitionist.

However, underlying an intuitionist position is an assumed principle: that we respect the dignity of our and each other's being as a prerequisite for the confidence we place in our and in other's moral positions. Acceptance of this obligation implies a willingness to take responsibility for the moral choices we make. This constitutes what I have postulated as the ethics of integrity: they imply respect for the dignity of our and each other's being, and responsibility for our moral choices. Elsewhere I have shown how the ethics of integrity may be postulated as a dialectical morality (Mason, 2000). As a dialectical morality, I have argued that the ethics of integrity is sensitive both to universalist positions and to nonfoundational moral positions, concluding that moral judgement and action are inescapably wrought by a tension between the objectivity of foundational commitment and solidarity's face-to-face responsibility.

Principles that I earlier indicated to be associated with multiculturalism, such as equal liberty, equal opportunity, justice, the fostering of critical judgement in education, asserted as transcultural by the likes of Robert Fullinwider, Amy Gutmann and Charles Taylor, are quickly able to be derived from these two principles of the ethics of integrity. For example, by the truth of the contrapositive, to deny somebody equal liberty and opportunity is to treat them without respect; hence to respect others implies that we acknowledge that they enjoy equal liberty and opportunity. 


\section{Conclusion}

If we accept, then, that we are morally obliged to treat others with respect, and that we are bound to accept the force of that which has been justified in reason, then we are committed to honouring the principle of multiculturalism. A commitment to multiculturalism (from which we cannot escape if we accept these premises) commits us to the universal applicability of its associated principles, which commits all to the transcultural normative reach of its principles. This means that we are bound to respect the right of all cultures to live in accordance with their own beliefs and practices, but only in so far as these beliefs and practices are consistent with the principles associated with multiculturalism itself, primary among which is the principle of respect for the rights of others. And we are committed to rejecting practices that violate this and its associated principles. From moral and epistemological principles that originated locally we are led inexorably to their normative reach across all cultures.

This is a hugely significant conclusion. It means, for example, that we are morally justified in condemning cultural practices that are not consistent with the Universal Declaration of Human Rights. It means, to answer our main question, that the implementation of education programmes in different cultures across the world, motivated, to use the example with which I introduced this paper, by a belief in the right of all to literacy and by a commitment to maximizing the life chances of all, is morally justified. We are indeed justified in implementing programmes founded in principles of equal respect and dignity in cultures that reject the ways in which we give expression to these principles. There are ethical principles and educational ideals that can be justified as applicable to all cultures, whether or not those cultures reject such principles and ideals.

But, as I mentioned in the introduction, such values might challenge the traditions and beliefs of members of different cultures, might indeed challenge the very fabric of their worldview and sources of existential meaning. Some cultures may not share our notions of equal respect and dignity when it comes to women, members of other ethnic groups and of lower castes, the poor, children. This far-reaching conclusion requires that we condemn the disrespectful treatment in our and in other cultures of women, members of other ethnic groups and of lower castes, the poor, children. But it requires that we tread very carefully and sensitively. We may in some cases be challenging some aspects of what might have been held dear for centuries. We may be challenging what others have for centuries held to be right, good and 
true. But at least we are challenging these practices in terms of the rights of every person to respect, human dignity, equal liberty and opportunity, and justice.

\section{References}

Bauman, Z. (1993) Postmodern Ethics (Oxford, Blackwell).

Cottingham, J. (1996) Western Philosophy: an anthology (Oxford, Blackwell).

Delanty, G. (2000) Citizenship in a Global Age: society, culture, politics (Buckingham, Open University Press).

Fullinwider, R.K. 1996. Multicultural Education: concepts, policies, and controversies, in: R.K. Fullinwider (ed.), Public Education in a Multicultural Society: policy, theory, critique (Cambridge, Cambridge University Press).

Giddens, A. (1998) The Third Way: the renewal of social democracy (Cambridge, Polity Press).

Gutmann, A. (1996) Challenges of Multiculturalism in Democratic Education, in: R.K. Fullinwider (ed.), Public Education in a Multicultural Society: policy, theory, critique (Cambridge, Cambridge University Press).

Goldberg, D.T. (1994) Introduction: multicultural conditions, in: D.T. Goldberg (ed.), Multiculturalism: a critical reader (Oxford, Blackwell).

Kant, I. (1949) The Critique of Practical Reason and Other Writings in Moral Philosophy [1788] (Chicago, University of Chicago Press).

Kant, I. (1990) Foundations of the Metaphysics of Morals [1785] (New York, Macmillan). Levinas, E. (1985) Ethics and Infinity: conversations with Philippe Nemo (Pittsburgh, Duquesne University Press).

Mason, M. 2000. Values in Multicultural Education: whose ethics?, in: M. Leicester, C. Modgil and S. Modgil (eds), Education, Culture and Values, Vol. IV: Moral Education and Pluralism (London, Falmer Press).

Mason, M. (2001) The Ethics of Integrity: educational values beyond postmodern ethics, Journal of Philosophy of Education, 35:1.

Rescher, N. (1988) Rationality: a philosophical inquiry into the nature and the rationale of reason (Oxford, Clarendon Press of Oxford University Press).

Rorty, R. (1982) Consequences of Pragmatism (Minneapolis, University of Minnesota Press). 
Rorty, R. (1985) Solidarity or Objectivity, in: J. Rajchman and C. West (eds) Post-analytic Philosophy (New York, Columbia University Press).

Ross, W. D. (1930) The Right and the Good (Oxford, Clarendon).

Siegel, H. (1997) Why Be Rational? justifying the commitment to rationality, in: Rationality Redeemed? further dialogues on an educational ideal (London, Routledge).

Siegel, H. (2002) Multiculturalism and the Possibility of Transcultural Educational and Philosophical Ideals, in: A. Malachowski (ed.) Richard Rorty: Vol. IV. (London, Sage).

Taylor, C. (1992) Multiculturalism and 'the Politics of Recognition', with commentary by A. Gutmann (ed.), S. Rockefeller, M. Walzer and S. Wolf (Princeton, Princeton University Press).

Waters, M. (1995) Globalization (Cambridge, Polity Press).

\footnotetext{
${ }^{1}$ I presented an earlier version of this paper under the title, Ethics and Intercultural Education, as an invited keynote address at the annual UNESCO education conference in Finland in June 2003. It is based on a revised version that I subsequently presented at a seminar of the Scottish branch of the Philosophy of Education Society of Great Britain.

${ }^{2}$ This section is developed from sections of my paper (2001), The Ethics of Integrity: educational values beyond postmodern ethics, Journal of Philosophy of Education, 35:1.

${ }^{3}$ Moral relativism is of course not immediately to be feared: recognition of the worth of moral perspectives other than those of one's own culture is certainly a well documented potential advantage of multicultural education. The problem lies rather in strong relativism: if a strongly relativist understanding of the world teaches us that we have no universal grounds from which to condemn racist or sexist practices in other cultures, then what is there to stop us from adopting an entirely instrumental orientation in our own world?

${ }^{4}$ This section is summarized from sections of my paper (2001), The Ethics of Integrity: educational values beyond postmodern ethics, Journal of Philosophy of Education, 35:1. A fuller rendition of the argument can be found there.
} 